\title{
DBBP: database of binding pairs in protein- nucleic acid interactions
}

\author{
Byungkyu Park', Hyungchan Kim², Kyungsook Han ${ }^{3 *}$ \\ From 2013 International Conference on Intelligent Computing (ICIC 2013) \\ Nanning, China. 28-31 July 2013
}

\begin{abstract}
Background: Interaction of proteins with other molecules plays an important role in many biological activities. As many structures of protein-DNA complexes and protein-RNA complexes have been determined in the past years, several databases have been constructed to provide structure data of the complexes. However, the information on the binding sites between proteins and nucleic acids is not readily available from the structure data since the data consists mostly of the three-dimensional coordinates of the atoms in the complexes.
\end{abstract}

Results: We analyzed the huge amount of structure data for the hydrogen bonding interactions between proteins and nucleic acids and developed a database called DBBP (DataBase of Binding Pairs in protein-nucleic acid interactions, http://bclab.inha.ac.kr/dbbp). DBBP contains 44,955 hydrogen bonds (H-bonds) of protein-DNA interactions and 77,947 $\mathrm{H}$-bonds of protein-RNA interactions.

Conclusions: Analysis of the huge amount of structure data of protein-nucleic acid complexes is labor-intensive, yet provides useful information for studying protein-nucleic acid interactions. DBBP provides the detailed information of hydrogen-bonding interactions between proteins and nucleic acids at various levels from the atomic level to the residue level. The binding information can be used as a valuable resource for developing a computational method aiming at predicting new binding sites in proteins or nucleic acids.

\section{Background}

Protein-nucleic acid interactions play an important role in many biological activities. Site-specific DNA-binding proteins or transcription factors (TFs) play important roles in gene regulations by forming protein complexes [1]. These protein-DNA complexes may bind alone or in combination near the genes whose expression they control [2]. For example, DNA-binding proteins may regulate the expression of a target gene [1], so proteinDNA interactions are important for DNA replication, transcription and gene regulations in general.

Protein-RNA interactions also have important roles in a wide variety of gene expression [3]. For instance, ribonucleoprotein particles (RNPs) bind to RNA in the posttranscriptional regulation of gene expression [4], and

\footnotetext{
* Correspondence: khan@inha.ac.kr

${ }^{3}$ School of Computer Science and Engineering, Inha University, Incheon, South Korea

Full list of author information is available at the end of the article
}

tRNAs bind to aminoacyl-tRNA synthetases to properly translate the genetic code into amino acids [5]. As protein and RNA mutually interact, RNA-binding proteins are essential molecules in degradation, localization, regulating RNA splicing, RNA metabolism, stability, translation, and transport [6]. Therefore, identification of amino acids involved in DNA/RNA binding or (ribo)nucleotides involved in amino acid binding is important for understanding of the mechanism of gene regulations.

As the number of structures of protein-DNA/RNA complexes that have been resolved has been increased plentifully for the past few years, a huge amount of structure data is available at several databases [7-10]. However, the data on the binding sites between proteins and nucleic acids is not readily available from the structure data, which consist mostly of the three-dimensional coordinates of the atoms in the complexes. A recent database called the Protein-RNA Interface Database (PRIDB) [9] provides the information on protein-RNA interfaces by showing 
interacting amino acids and ribonucleotides in the primary sequences. However, it does not provide the binding sites on the interacting partners of the amino acids and ribonucleotides in protein-RNA interfaces.

In this study we performed wide analysis of the structures of protein-DNA/RNA complexes and built a database called DBBP (DataBase of Binding Pairs in protein-nucleic acid interactions). The database shows hydrogen-bonding interactions between proteins and nucleic acids at an atomic level, which is not readily available in any other databases, including the Protein Data Bank (PDB) [11]. The binding pairs of hydrogen bonds provided by the database will help researchers determine DNA (or RNA) binding sites in proteins and protein binding sites in DNA or RNA molecules. It can also be used as a valuable resource for developing a computational method aiming at predicting new binding sites in proteins or nucleic acids. The rest of the paper presents the structure and interface of the database.

\section{Materials and methods}

\section{Protein-DNA/RNA complexes}

The protein-DNA/RNA complexes determined by X-ray crystallography were selected from PDB. As of February, 2013 there were 2,568 protein-DNA complexes and 1,355 protein-RNA complexes in PDB. After extracting complexes with a resolution of $3.0 \AA$ or better, 2,138 protein-DNA complexes (called the DS1 data set) and 651 protein-RNA complexes (the DS2 data set) remained.

\section{Binding sites in protein-nucleic acid interactions}

Different studies [9,12-14] have defined slightly different criteria for a binding site in protein-nucleic acid interactions. For example, in RNABindR $[15,16]$ and BindN [17] an amino acid with an atom within a distance of $5 \AA$ from any other atom of a ribonucleotide was considered to be an RNA-binding amino acid.

As for the criteria for a binding site between proteins and nucleic acids, we use a hydrogen bond (H-bond), which is stricter than the distance criteria. The locations of hydrogen atoms $(\mathrm{H})$ were inferred from the surrounding atoms since hydrogen atoms are invisible in purely $\mathrm{X}$-ray-derived structures. $\mathrm{H}$-bonds between proteins and nucleic acids were identified by finding all proximal atom pairs between $\mathrm{H}$-bond donors (D) and acceptors (A) that satisfy the following the geometric criteria: (1) the hydrogen-acceptor (H-A) distance $<2.5 \AA$, (2) the donor-hydrogen-acceptor (D-H-A) angle $>90^{\circ}$, (3) the contacts with the donor-acceptor (D-A) distance < $3.9 \AA$, (4) H-A-AA angle $>90^{\circ}$, where AA is an acceptor antecedent. These are the most commonly used criteria for $\mathrm{H}$ bonds. In particular, the criteria of H-A distance $<2.5 \AA$ and D-H-A angle $>90^{\circ}$ are essential for $\mathrm{H}$ bonds [18]. If there is no $\mathrm{H}$-bond within a protein-nucleic acid complex, we eliminated the complex from the data sets of DS1 and DS2. As a result, we gathered 2,068 protein-DNA complexes (DS3) and 637 protein-RNA complexes (DS4).

As an example, Figure 1 shows three $\mathrm{H}$-bonds between Threonine (Thr224) and Cytosine (C8) in a protein-RNA complex (PDB ID: 4F3T) [19]. In protein-RNA interactions, OG1 and $\mathrm{N}$ of Threonine can act as a hydrogen donor and OG1 and $\mathrm{O}$ of Threonine can act as a hydrogen acceptor. N3, N4, O2' and O3' of Cytosine can act as a hydrogen donor and $\mathrm{N} 3, \mathrm{O} 2, \mathrm{O}^{\prime}, \mathrm{O}^{\prime}, \mathrm{O}^{\prime}, \mathrm{O}^{\prime}, \mathrm{OP} 1$ and OP2 of Cytosine can act as a hydrogen acceptor. In this example, Cytosine is the 8th nucleotide in RNA chain R and Threonine is the 224th amino acid in protein chain A. OG1 of Threonine donates hydrogen to O2' of Cytosine, OG1 of Threonine donates hydrogen to O3' of Cytosine, and O2' of Cytosine donates hydrogen to OG1 of Threonine. Figure 2 shows the structure of the protein-RNA complex (PDB ID: 4F3T).

\section{The probability of binding amino acid}

Let $P(+)$ be the probability that an amino acid is a binding site and $P(-)$ be the probability that an amino acid is a non-binding site in protein-nucleic acid interactions (Equations 1 and 2).

$$
\begin{aligned}
& P(+)=\frac{\text { DNA/RNA - binding amino acids }}{\text { amino acids in protein - DNA/RNA complexes }} \\
& P(-)=\frac{\text { DNA/RNA - non - binding amino acids }}{\text { amino acids in protein - DNA/RNA complexes }}
\end{aligned}
$$

Then, the conditional probability $P(A \mid+)$ is the probability that the binding amino acid is A. Likewise, the conditional probability $P(A \mid-)$ is the probability that the non-binding amino acid is A. Equation 5 is the log-likelihood ratio of $P(A \mid+)$ and $P(A \mid-)$.

$$
\begin{aligned}
& P(A \mid+)=\frac{P(A \cap+)}{P(+)} \\
& P(A \mid-)=\frac{P(A \cap+)}{P(-)} \\
& \log -\text { likelihoodratio }=\log _{2} \frac{P(A \mid+)}{P(A \mid-)}
\end{aligned}
$$

\section{Results and discussion}

Hydrogen bonds in protein-nucleic acid interactions We obtained $\mathrm{H}$-bonds from 2,068 protein-DNA complexes (DS3) and 637 protein-RNA complexes (DS4) using HBPLUS $[18,20]$ with the $\mathrm{H}$-bond criteria: $\overline{H A}<2.5 \AA, \angle D H A>90^{\circ}, \overline{D A}<3.9 \AA$. There are a 


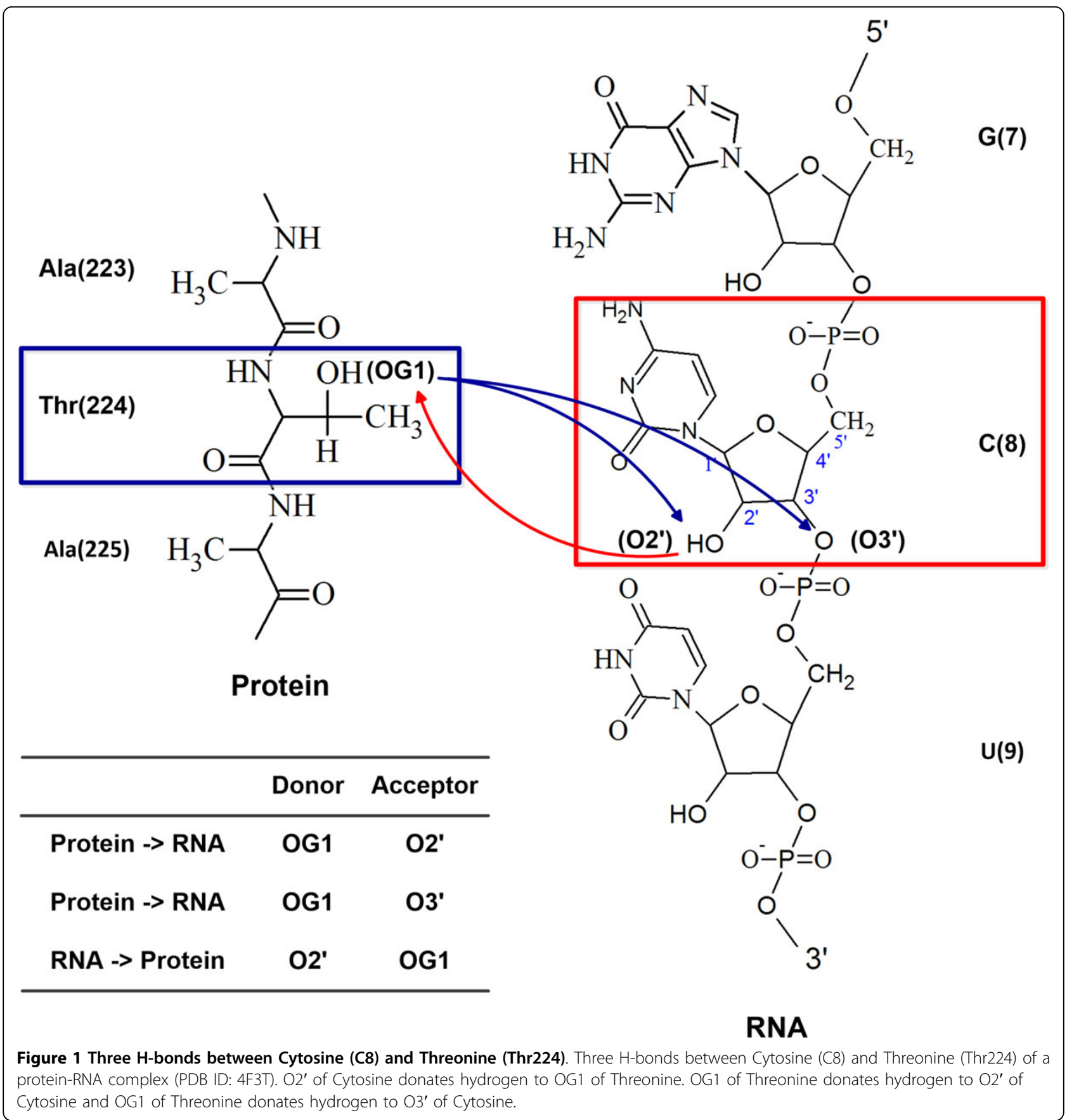

total of 44,955 H-bonds in protein-DNA complexes and $77,947 \mathrm{H}$-bonds in protein-RNA complexes. Table 1 shows the number of atoms, which are occurrences in $\mathrm{H}$-bonds of amino acids. In the 44,955 H-bonds of protein-DNA complexes, there are 41,298 hydrogen donors and 3,657 hydrogen acceptors in amino acids. In the $77,947 \mathrm{H}$-bonds of protein-RNA complexes, there are 59,796 hydrogen donors and 18,151 hydrogen acceptors in amino acids. Table 2 shows the number of atoms, which are occurrences in $\mathrm{H}$-bonds of (ribo)nucleotides.
In the $44,955 \mathrm{H}$-bonds of protein-DNA complexes, there are 3,657 hydrogen donors and 41,298 hydrogen acceptors in DNAs. In the 77,947 H-bonds of proteinRNA complexes, there are 18,151 hydrogen donors and 59,796 hydrogen acceptors in RNAs.

If an atom of DNA acts as a hydrogen acceptor, an atom of protein should be a hydrogen donor. Hence, the number of DNA acceptors $(41,298)$ is the same as the number of protein donors $(41,298)$, and the number of DNA donors $(3,657)$ is the same as the number of protein 


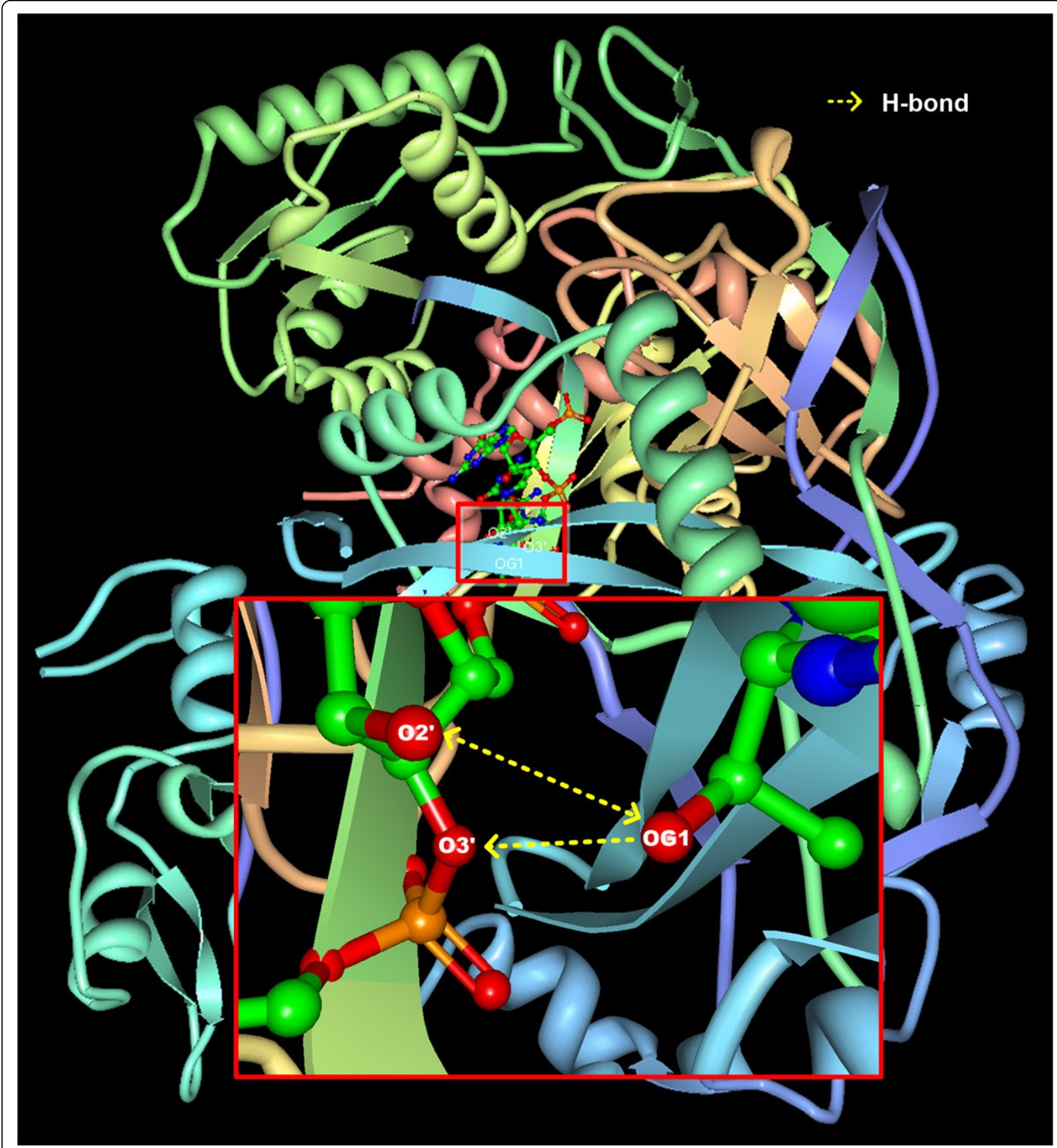

Figure 2 The structure of a protein-RNA complex (PDB ID: 4F3T). The enlarged box shows three hydrogen bonds between Cytosine and Threonine. O2' donates hydrogen to OG1. OG1 donates hydrogen to O2' and O3'.

acceptors $(3,657)$. Likewise, the number of RNA acceptors $(59,796)$ is the same as the number of protein donors $(59,796)$ and the number of RNA donors $(18,151)$ is the same as the number of protein acceptors $(18,151)$.

Figure 3 shows RNA-binding amino acids in proteinRNA complexes. Ala, Arg, Glu, Gly, Leu, Lys, and Val are more frequent than others in protein-RNA complexes (Figure 3A). In binding sites with RNA, Arg has the most frequently observed amino acid. Figure 3C shows the log-likelihood ratio (Equation 5) for each amino acid. Amino acids with a positive log-likelihood ratio have a higher chance to bind to RNA than those with a negative log-likelihood ratio. Arg has the highest log-likelihood ratio (1.59), and Val has the lowest log- 
Table 1 Atoms of amino acids involved in H-bonding interactions with nucleic acids.

\begin{tabular}{|c|c|c|c|c|c|c|c|}
\hline \multirow[b]{2}{*}{ AA } & \multirow[b]{2}{*}{ Atom } & \multicolumn{3}{|c|}{ RNA-protein complex } & \multicolumn{3}{|c|}{ DNA-protein complex } \\
\hline & & Acceptor & Donor & \#H-bonds & Acceptor & Donor & \#H-bonds \\
\hline \multirow[t]{3}{*}{ Ala } & $\mathrm{N}$ & & 1,069 & 1,653 & & 674 & 808 \\
\hline & $\mathrm{O}$ & 567 & & & 134 & & \\
\hline & OXT & 17 & & & & & \\
\hline \multirow[t]{6}{*}{$\overline{\operatorname{Arg}}$} & $\mathrm{NH} 2$ & & 9,252 & 22,395 & & 6,144 & 13,705 \\
\hline & $\mathrm{NH} 1$ & & 7,278 & & & 4,665 & \\
\hline & $\mathrm{NE}$ & & 4,011 & & & 2,191 & \\
\hline & $\mathrm{N}$ & & 1,388 & & & 606 & \\
\hline & $\mathrm{O}$ & 455 & & & 99 & & \\
\hline & OXT & 13 & & & & & \\
\hline \multirow[t]{4}{*}{ Asn } & ND2 & & 3,268 & 4,953 & & 2349 & 3,119 \\
\hline & OD1 & 934 & & & 408 & & \\
\hline & $\mathrm{N}$ & & 549 & & & 261 & \\
\hline & $\mathrm{O}$ & 202 & & & 101 & & \\
\hline \multirow[t]{4}{*}{$\overline{A s p}$} & OD2 & 1,416 & & 2,829 & 353 & & 735 \\
\hline & OD1 & 1,183 & & & 290 & & \\
\hline & $\mathrm{O}$ & 178 & & & 31 & & \\
\hline & $\mathrm{N}$ & & 52 & & & 61 & \\
\hline \multirow[t]{3}{*}{ Cys } & SG & 23 & 76 & 125 & 19 & 120 & 215 \\
\hline & $\mathrm{O}$ & 24 & & & & & \\
\hline & $\mathrm{N}$ & & 2 & & & 76 & \\
\hline \multirow[t]{4}{*}{$G \ln$} & NE2 & 168 & 2496 & 4,468 & 2 & 1,593 & 2,571 \\
\hline & OE1 & 1,108 & & & 363 & 521 & \\
\hline & $\mathrm{N}$ & & 480 & & & & \\
\hline & 0 & 216 & & & 92 & & \\
\hline \multirow[t]{4}{*}{ Glu } & OE2 & 1,691 & & 3,507 & 275 & & 737 \\
\hline & OE1 & 1,315 & & & 260 & & \\
\hline & $\mathrm{O}$ & 193 & & & 19 & & \\
\hline & $\mathrm{N}$ & & 308 & & & 183 & \\
\hline \multirow[t]{3}{*}{ Gly } & $\mathrm{N}$ & & 1,518 & 2,699 & & 1749 & 1,902 \\
\hline & O & 1,175 & & & 153 & & \\
\hline & OXT & 6 & & & & & \\
\hline \multirow[t]{4}{*}{ His } & NE2 & 412 & 1,454 & 3,591 & 30 & 768 & 1,254 \\
\hline & ND1 & 536 & 1,014 & & 15 & 327 & \\
\hline & $\mathrm{N}$ & & 106 & & & 90 & \\
\hline & 0 & 69 & & & 24 & & \\
\hline \multirow[t]{3}{*}{ lle } & $\mathrm{N}$ & & 258 & 309 & & 433 & 466 \\
\hline & O & 40 & & & 33 & & \\
\hline & OXT & 11 & & & & & \\
\hline \multirow[t]{2}{*}{$\overline{\text { Leu }}$} & $\mathrm{N}$ & & 507 & 766 & & 362 & 387 \\
\hline & 0 & 259 & & & 25 & & \\
\hline \multirow[t]{4}{*}{ Lys } & $N Z$ & & 9,864 & & & 5,145 & 6,351 \\
\hline & $\mathrm{N}$ & & 852 & 11,436 & 86 & 1,120 & \\
\hline & 0 & 717 & & & & & \\
\hline & OXT & 3 & & & & & \\
\hline \multirow[t]{4}{*}{$\overline{\text { Met }}$} & SD & 105 & & 662 & 15 & & 147 \\
\hline & O & 276 & & & 13 & 119 & \\
\hline & $\mathrm{N}$ & & 278 & & & & \\
\hline & OXT & 3 & & & & & \\
\hline
\end{tabular}


Table 1 Atoms of amino acids involved in H-bonding interactions with nucleic acids. (Continued)

\begin{tabular}{|c|c|c|c|c|c|c|c|}
\hline \multirow[t]{2}{*}{ Phe } & 0 & 333 & & 539 & 42 & & 247 \\
\hline & $\mathrm{N}$ & \multicolumn{3}{|c|}{206} & \multicolumn{3}{|c|}{205} \\
\hline Pro & 0 & 161 & & 161 & 28 & & 28 \\
\hline \multirow[t]{3}{*}{ Ser } & OG & 1,179 & 4,675 & 6,997 & 182 & 3,533 & 4,741 \\
\hline & $\mathrm{N}$ & & 683 & & & 958 & \\
\hline & O & 460 & & & 68 & & \\
\hline \multirow[t]{3}{*}{ Thr } & OG1 & 1,058 & 4,406 & 7,267 & 158 & 3,017 & 4,252 \\
\hline & O & 750 & & & 132 & & \\
\hline & $\mathrm{N}$ & & 1,053 & & & 945 & \\
\hline \multirow[t]{4}{*}{$\overline{\operatorname{Trp}}$} & NE1 & & 532 & 582 & & 358 & 393 \\
\hline & OXT & 16 & & & & & \\
\hline & O & 14 & & & 10 & & \\
\hline & $\mathrm{N}$ & & 20 & & & 25 & \\
\hline \multirow[t]{3}{*}{ Tyr } & $\mathrm{OH}$ & 597 & 1,935 & 2,682 & 133 & 1,800 & 2,511 \\
\hline & O & 93 & & & 28 & & \\
\hline & $\mathrm{N}$ & & 57 & & & 550 & \\
\hline \multirow[t]{4}{*}{$\overline{\mathrm{Val}}$} & O & 174 & & 326 & 36 & & 386 \\
\hline & $\mathrm{N}$ & & 151 & & & 350 & \\
\hline & OXT & 1 & & & & & \\
\hline & & 18,151 & 59,796 & 77,947 & 3,657 & 41,298 & 44,955 \\
\hline
\end{tabular}

Table 2 Atoms of nucleotides involved in H-bonding interactions with amino acids.

\begin{tabular}{|c|c|c|c|c|c|c|c|}
\hline \multirow[b]{2}{*}{ Nucleotide } & \multirow[b]{2}{*}{ Atom } & \multicolumn{3}{|c|}{ RNA-protein complex } & \multicolumn{3}{|c|}{ DNA-protein complex } \\
\hline & & Acceptor & Donor & \#H-bonds & Acceptor & Donor & \#H-bonds \\
\hline \multirow[t]{10}{*}{ A } & N1 & 402 & 140 & 22,103 & 58 & 23 & 10,254 \\
\hline & N3 & 1,071 & 79 & & 748 & 26 & \\
\hline & N6 & & 1,472 & & & 621 & \\
\hline & N7 & 505 & & & 580 & & \\
\hline & $\mathrm{O} 2^{\prime}$ & 4,240 & 4,269 & & & & \\
\hline & O3' & 1,711 & 86 & & 361 & 100 & \\
\hline & O4' & 252 & & & 276 & & \\
\hline & O5' & 110 & & & 188 & & \\
\hline & OP1 & 1,754 & & & 4,039 & & \\
\hline & OP2 & 6,012 & & & 3,234 & & \\
\hline \multirow[t]{9}{*}{ C } & N3 & 335 & 49 & 16,189 & 127 & 3 & 9,502 \\
\hline & N4 & & 785 & & & 1,272 & \\
\hline & $\mathrm{O} 2$ & 2,556 & & & 959 & & \\
\hline & $\mathrm{O} 2^{\prime}$ & 2,101 & 2,209 & & 1 & 1 & \\
\hline & O3' & 1,150 & 56 & & 257 & 139 & \\
\hline & O4' & 663 & & & 209 & & \\
\hline & $\mathrm{O} 5^{\prime}$ & 117 & & & 118 & & \\
\hline & OP1 & 5,176 & & & 3,858 & & \\
\hline & OP2 & 992 & & & 2,558 & & \\
\hline \multirow[t]{8}{*}{$G$} & $\mathrm{~N} 1$ & 547 & 759 & 30,350 & 2 & 204 & 14,864 \\
\hline & N2 & & 3,907 & & & 761 & \\
\hline & N3 & 655 & 53 & & 399 & 2 & \\
\hline & N7 & 1,660 & & & 2,238 & & \\
\hline & $\mathrm{O} 2^{\prime}$ & 2,047 & & & 2,383 & & \\
\hline & O3' & 1,031 & 24 & & 438 & 157 & \\
\hline & O4' & 450 & & & 420 & & \\
\hline & O5' & 585 & & & 197 & & \\
\hline
\end{tabular}


Table 2 Atoms of nucleotides involved in H-bonding interactions with amino acids. (Continued)

\begin{tabular}{|c|c|c|c|c|c|c|c|}
\hline & O6 & 2,396 & & & 2,272 & & \\
\hline & OP1 & 10,523 & & & 4,359 & & \\
\hline & OP2 & 3,330 & & & 3,415 & & \\
\hline \multirow[t]{10}{*}{$\mathrm{U} / \mathrm{T}$} & N3 & 173 & 386 & 9,305 & 29 & 234 & 10,335 \\
\hline & $\mathrm{O} 2$ & 1,561 & & & 1,165 & & \\
\hline & $\mathrm{O} 2^{\prime}$ & 1,310 & 1,445 & & & & \\
\hline & O3' & 1,067 & 49 & & 351 & 114 & \\
\hline & $\mathrm{O} 4$ & 1,199 & & & 796 & & \\
\hline & O $4^{\prime}$ & 166 & & & 257 & & \\
\hline & O5' & 45 & & & 216 & & \\
\hline & OP1 & 1,108 & & & 3,548 & & \\
\hline & OP2 & 796 & & & 3,625 & & \\
\hline & 59,796 & & 18,151 & 77,947 & 41,298 & 3,657 & 44,955 \\
\hline
\end{tabular}

likelihood ratio (-4.24). Interestingly, Ala has a negative log-likelihood ratio although it is frequently observed in protein-RNA complexes. This is because Ala is rarely observed in binding sites.

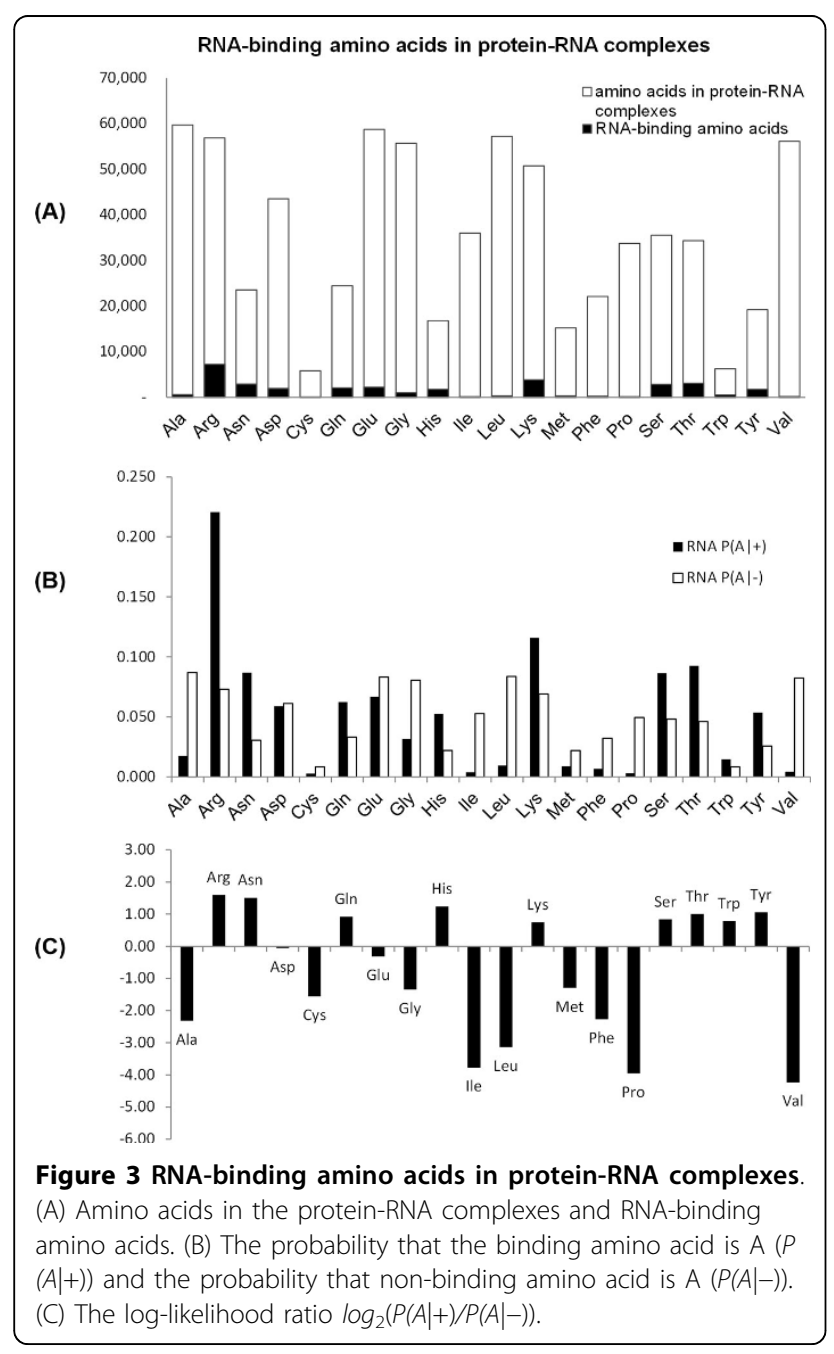

Figure 4 shows DNA-binding amino acids in proteinDNA complexes. Ala, Arg, Glu, Gly, Leu, Lys, Ser, and Val are more frequent than others in protein-DNA complexes (Figure 4A). As in protein-RNA interactions, Arg

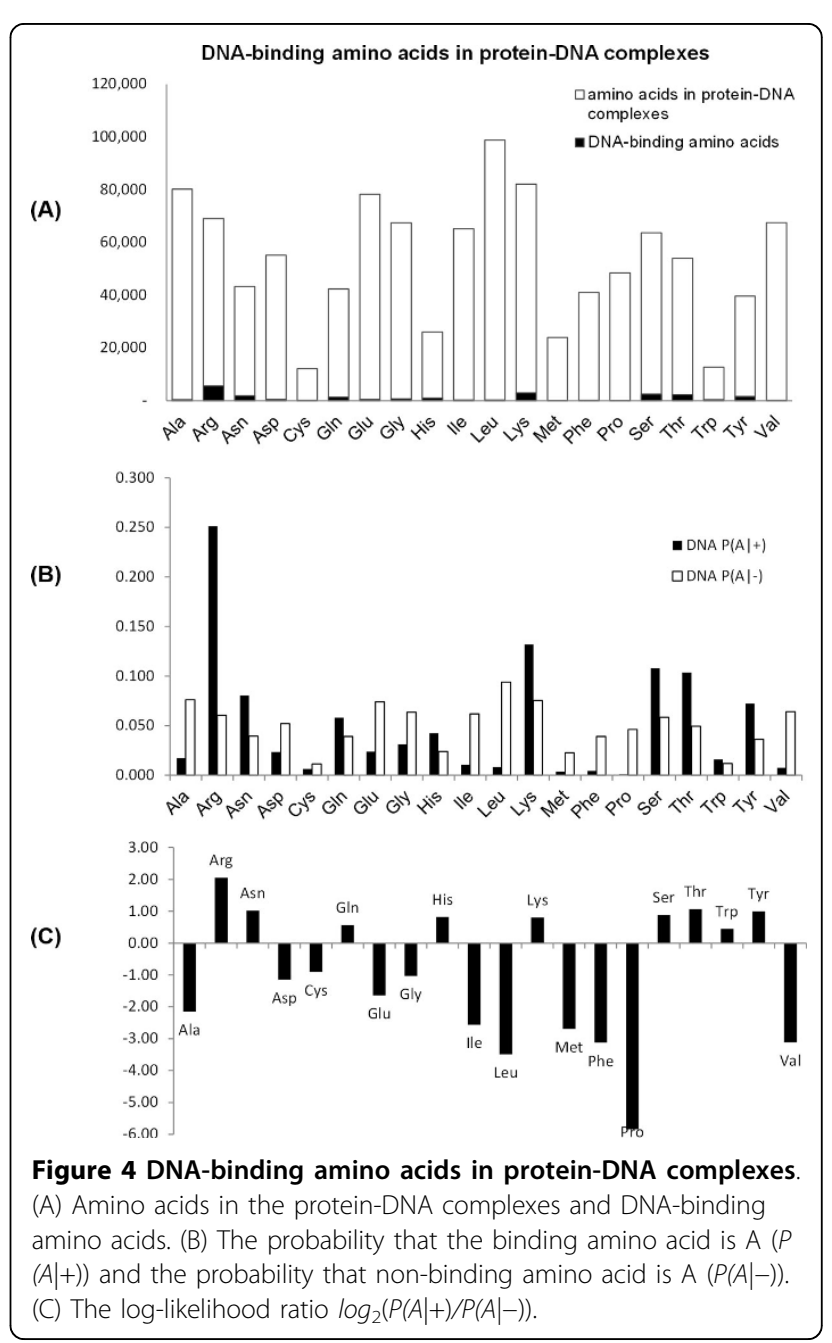


has the most frequently observed amino acid in the binding sites with DNA.

\section{Web interface}

DBBP shows binding pairs at various levels, from the atomic level to the residue level. When it shows detailed information on H-Bonds, it shows the donors and acceptors of each H-bond. A same type of atom can play a role of hydrogen donor or acceptor depending on the context. We generated XML files for binding sites of proteinDNA/RNA complexes. Users of the database can access the XML file via PDB ID.

Figure 5 shows our XML schema. The BindPartner element has elements and attributes, which are PDB ID, protein sequence (proSeq), protein bond (proBnd), DNA/RNA sequence (dnaSeq, rnaSeq), and DNA/RNA bond (dnaBnd, rnaBnd). DNA/RNA and protein bonds represent binding site ' + ' and non-binding site '-'. The BindingSite element has attributes, which are PDBID, Acceptor, Acceptor chain, Acceptor index, Acceptor residue, Donor, Donor chain, Donor index, and Donor residue.

\section{Conclusion}

From an extensive analysis of the structure data of protein-DNA/RNA complexes extracted from PDB, we have identified hydrogen bonds (H-bonds). Analysis of the large amount of structure data for $\mathrm{H}$-bonds is laborintensive, yet provides useful information for studying protein-nucleic acid interactions. The protein-DNA complexes contain 44,955 H-bonds, which have 3,657 hydrogen acceptors (HA) and 41,298 hydrogen donors (HD) in amino acids, and 41,298 HA and 3,657 HD in nucleotides. The protein-RNA complexes contain 77,947 $\mathrm{H}$-bonds, which have $18,151 \mathrm{HA}$ and 59,796 HD in amino acids, and 59,796 HA and 18,151 HD in nucleotides. Using the data of $\mathrm{H}$-bonding interactions, we developed a database called DBBP (DataBase of Binding Pairs in protein-nucleic acid interactions). DBBP provides the detailed information of $\mathrm{H}$-bonding interactions

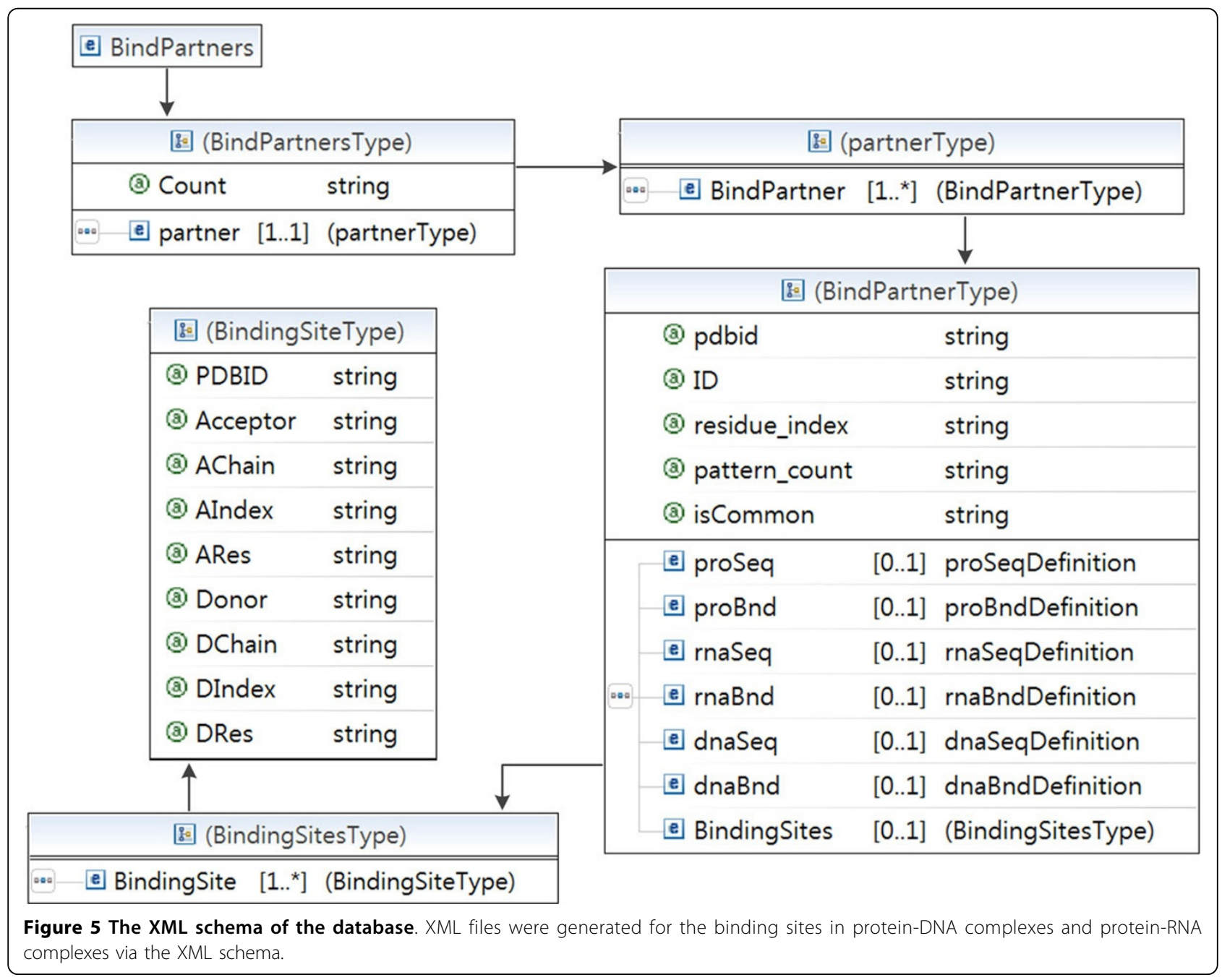


between proteins and nucleic acids at various levels. Such information is not readily available in any other databases, including $\mathrm{PDB}$, but will help researchers determine DNA (or RNA) binding sites in proteins and protein binding sites in DNA or RNA molecules. It can also be used as a valuable resource for developing a computational method aiming at predicting new binding sites in proteins or nucleic acids. The database is available at http://bclab.inha.ac.kr/dbbp.

\section{Authors' contributions}

Byungkyu Park implemented the databse and prepared the first draft of the manuscript. Hyungchan Kim drew figures and prepared the manuscript together. Kyungsook Han supervised the work and rewrote the manuscript All authors read and approved the final manuscript.

\section{Acknowledgements}

This work was funded by the Ministry of Science, ICT and Future Planning (2012R1A1A3011982) and the Ministry of Education (2010-0020163) of Republic of Korea. The cost of the article was funded by the Ministry of Science, ICT and Future Planning (2012R1A1A3011982).

This article has been published as part of BMC Bioinformatics Volume 15 Supplement 15, 2014: Proceedings of the 2013 International Conference on Intelligent Computing (ICIC 2013). The full contents of the supplement are available online at http://www.biomedcentral.com/bmcbioinformatics/ supplements/15/S15

\section{Authors' details}

${ }^{1}$ Institute for Information and Electronics Research, Inha University, Incheon, South Korea. ${ }^{2}$ Department of Chemistry, Inha University, Incheon, South Korea. ${ }^{3}$ School of Computer Science and Engineering, Inha University, Incheon, South Korea.

Published: 3 December 2014

\section{References}

1. Simicevic J, Deplancke B: DNA-centered approaches to characterize regulatory protein-DNA interaction complexes. Molecular Biosystems 6(3):462-468.

2. Berger MF, Bulyk ML: Universal protein-binding microarrays for the comprehensive characterization of the DNA-binding specificities of transcription factors. Nature Protocols 2009, 4(3):393-411.

3. Licatalosi DD, Mele A, Fak JJ, Ule J, Kayikci M, Chi SW, Clark TA, Schweitzer AC, Blume JE, Wang XN, Darnell JC, Darnell RB: HITS-CLIP yields genome-wide insights into brain alternative RNA processing. Nature 456(7221):464-U22.

4. Varani $G$, Nagai $K$ : RNA recognition by RNP proteins during RNA processing. Annual Review of Biophysics and Biomolecular Structure 1998, 27:407-445.

5. Moras D: Aminoacyl-tRNA synthetases. Current Opinion in Structural Biology 1992, 2:138-142

6. van Kouwenhove M, Kedde M, Agami R: MicroRNA regulation by RNAbinding proteins and its implications for cancer. Nature Reviews Cancer 2011, 11(9):644-656.

7. Contreras-Moreira B: 3D-footprint: a database for the structural analysis of protein-DNA complexes. Nucleic Acids Research 2010, 38(suppl 1):D91-D97.

8. Hoffman MM, Khrapov MA, Cox JC, Yao J, Tong L, Ellington AD: AANT: the Amino Acid-Nucleotide Interaction Database. Nucleic Acids Research 2004, 32(suppl 1):D174-D181.

9. Lewis BA, Walia RR, Terribilini M, Ferguson J, Zheng C, Honavar V, Dobbs D: PRIDB: a protein-RNA interface database. Nucleic Acids Research 2011, 39 : D277-D282.

10. Xie Z, Hu S, Blackshaw S, Zhu H, Qian J: hPDI: a database of experimental human protein-DNA interactions. Bioinformatics 2010, 26(2):287-289.

11. Berman HM, Westbrook J, Feng Z, Gilliland G, Bhat TN, Weissig H, Shindyalov IN, Bourne PE: The Protein Data Bank. Nucleic Acids Research 2000, 28:235-242.
12. Allers J, Shamoo Y: Structure-based analysis of Protein-RNA interactions using the program ENTANGLE. Journal of Molecular Biology 2001 311:75-86.

13. Norambuena T, Melo F: The Protein-DNA Interface database. BmC Bioinformatics 2010, 11.

14. Kirsanov DD, Zanegina ON, Aksianov EA, Spirin SA, Karyagina AS, Alexeevski AV: NPIDB: nucleic acid-protein interaction database. Nucleic Acids Research 2013, 41(D1):D517-D523.

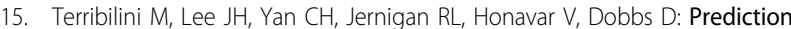
of RNA binding sites in proteins from amino acid sequence. Rna- $a$ Publication of the Rna Society 2006, 12(8):1450-1462.

16. Terribilini M, Sander JD, Lee JH, Zaback P, Jernigan RL, Honavar V, Dobbs D: RNABindR: a server for analyzing and predicting RNA-binding sites in proteins. Nucleic Acids Research 35:W578-W584.

17. Wang LJ, Brown SJ: BindN: a web-based tool for efficient prediction of DNA and RNA binding sites in amino acid sequences. Nucleic Acids Research 2006, 34:W243-W248.

18. Torshin IY, Weber IT, Harrison RW: Geometric criteria of hydrogen bonds in proteins and identification of 'bifurcated' hydrogen bonds. Protein Engineering 2002, 15(5):359-363.

19. Elkayam E, Kuhn CD, Tocilj A, Haase AD, Greene EM, Hannon GJ, JoshuaTor $L$ : The Structure of Human Argonaute-2 in Complex with miR-20a. Cell 2012, 150:100-110.

20. McDonald IK, Thornton JM: Satisfying Hydrogen-Bonding Potential in Proteins. Journal of Molecular Biology 1994, 238(5):777-793.

doi:10.1186/1471-2105-15-S15-S5

Cite this article as: Park et al.: DBBP: database of binding pairs in protein-nucleic acid interactions. BMC Bioinformatics 2014 15(Suppl 15):S5.

\section{Submit your next manuscript to BioMed Central and take full advantage of:}

- Convenient online submission

- Thorough peer review

- No space constraints or color figure charges

- Immediate publication on acceptance

- Inclusion in PubMed, CAS, Scopus and Google Scholar

- Research which is freely available for redistribution

Submit your manuscript at www.biomedcentral.com/submit
C Biomed Central 